\section{Global Alliance of Tertiary Education and Sustainable Development}

\author{
Petra Molthan-Hill ${ }^{1}$, Lina Erlandsson ${ }^{1}$, \\ Tabani Ndlovu ${ }^{1}$, Iain Patton ${ }^{2}$ and \\ Fiona Goodwin ${ }^{2}$ \\ ${ }^{1}$ Nottingham Trent University, Nottingham, UK \\ ${ }^{2}$ EAUC, Cheltenham, UK
}

\section{Synonyms}

HESI; International networks of HEIs; SDG Accord; Student networks

\section{Introduction}

\section{Global Alliance-Definition}

Launched in 2015, the Global Alliance of Tertiary Education and Student Sustainability Networks consists of 37 higher education networks, all working toward embedding sustainability in the center of higher education. The informal alliance is the world's largest alliance of both international and national networks, engaging partnerships on six continents (EAUC 2019a).

The main aim of the Global Alliance is to bring together higher education institutions around a common theme and work as a joint voice to make the collective impact which they cannot make alone. By focusing on international collaboration, the Alliance brings together partnerships from across the globe, enabling member networks to contribute with their own unique knowledge and experience to share good practice and efficiently address sustainability challenges.

This Global Alliance works in line with several international initiatives, including the Paris Climate Agreement throu an Open Letter to COP21 signed by 70 s HE networks, the UN Sustainable Development Goals (SDGs) through the SDG Accord, as well as other UN initiatives such as the UN Environment's Global Universities Partnership on Environment and Sustainability and the Higher Education Sustainability Initiative (HESI) (EAUC 2019a) which is currently reforming as the UN Environment Youth and Education Alliance.

\section{History a Rackground}

Higher ention institutions (HEIs) could be major contributors to changes in society toward sustainable development (Cortese 2003); however HEIs have been slow in taking up the new paradigms associated with sustainable development (Fien 2002). In 2011, for example, only 15 out of 14,000 HEIs had published sustainability reports (Lozano 2011). Nevertheless, some universities as well as individuals and groups had started very early to highlight the necessity that the HEI sector should address environmental problems. The Talloires Declaration signed in 1990 by 20 vice-chancellors, presidents, and university rectors across the world was the first of 
many declarations where universities tried to work together and commit themselves to achieve certain goals in curricula, research, operations, and outreach (Lozano et al. 2011). Since then national and international networks were initiated, many will be portrayed in this entry as they later formed the Global Alliance. At the beginning of this century, more and more actors in the different networks realized that taking a strategic approach would benefit the integration of sustainability in the higher education sector and subsequently in society. Utilizing the Framework for Strategic Sustainable Development, Dyer and Dyer (2017, p. 112) demonstrated how such an approach would support planning in complex systems and moving the whole sect $\bigcirc$ ward sustainability encompassing five levels, he following applied to the Global Alliance by the authors:

1. Understanding the functioning of the systems "human society within the biosphere"

2. Basic principles, for example, the focus on the UN Sustainable Development Goals

3. Strategy - a focus in the SDG Accord on leadership, education, research, operations, administrations, and engagement activities

4. Action - concrete steps, which are outlined in the reporting structure of the SDG Accord

5. Tools - sharing the tools which demonstrate best practice within the signatories of the SDG Accord

The following figure puts the formation of the Global Alliance and the development of the SDG Accord in a historical and strategic context; the aim of the Global Alliance is the contribution of the HEIs to achieving the UN SDGs by 2030 (Fig. 1).

\section{Key Organizations Contributing to the Global Alliance}

The Global Alliance is supported by a range of very diverse networks. Figure 2 gives a first overview of the different networks they reach (national or international) and the topics they choose to address. As can be seen in Fig. 2, most of the international and national networks focus on social and environmental issues, and many have chosen to support the UN SDGs in their entirety; however Fig. 2 is only a first attempt in illustrating the positioning of the different networks and will need further dialogue with all networks involved.

On the following pages, each of the networks as part of the Global Alliance is shortly introduced, their main aims and projects summarized, and information on the size of their memberships provided. Contact information can be obtained from the websites provided, and HEIs who want to engage in one or more networks are encouraged to get in contact with the network of their choice.

\section{Association for the Advancement of Sustainability in Higher Education (AASHE)} Launched in 2005, AASHE is the first North American association working for campus sustainability by providing support for higher education institutions across the United States, Canada, and beyond (AASHE 2019a). AASHE aims to lead the advancement of sustainability themes within the further and higher education sector and enable academics, professional staff, and students to contribute to a more sustainable future (AASHE 2019b). The association offers online resources, webinars, and workshops, as well as an annual conference, to enable their over 900 members from 20 countries to champion the sustainability agenda (AASHE 2019c).

AASHE leads the Sustainability Tracking, Assessment and Rating System (STARS), a framework that allows universities and colleges to self-report on their sustainability performance. Participating institutions can receive a STARS Bronze, Silver, Gold, or Platinum rating on the STARS Reporter designation to show their commitment to sustainability. The framework allows higher education institutions to give an understanding of sustainability for both students and staff, set goals, and create a long-term contingency plan to improve sustainability on campus (STARS 2019). 


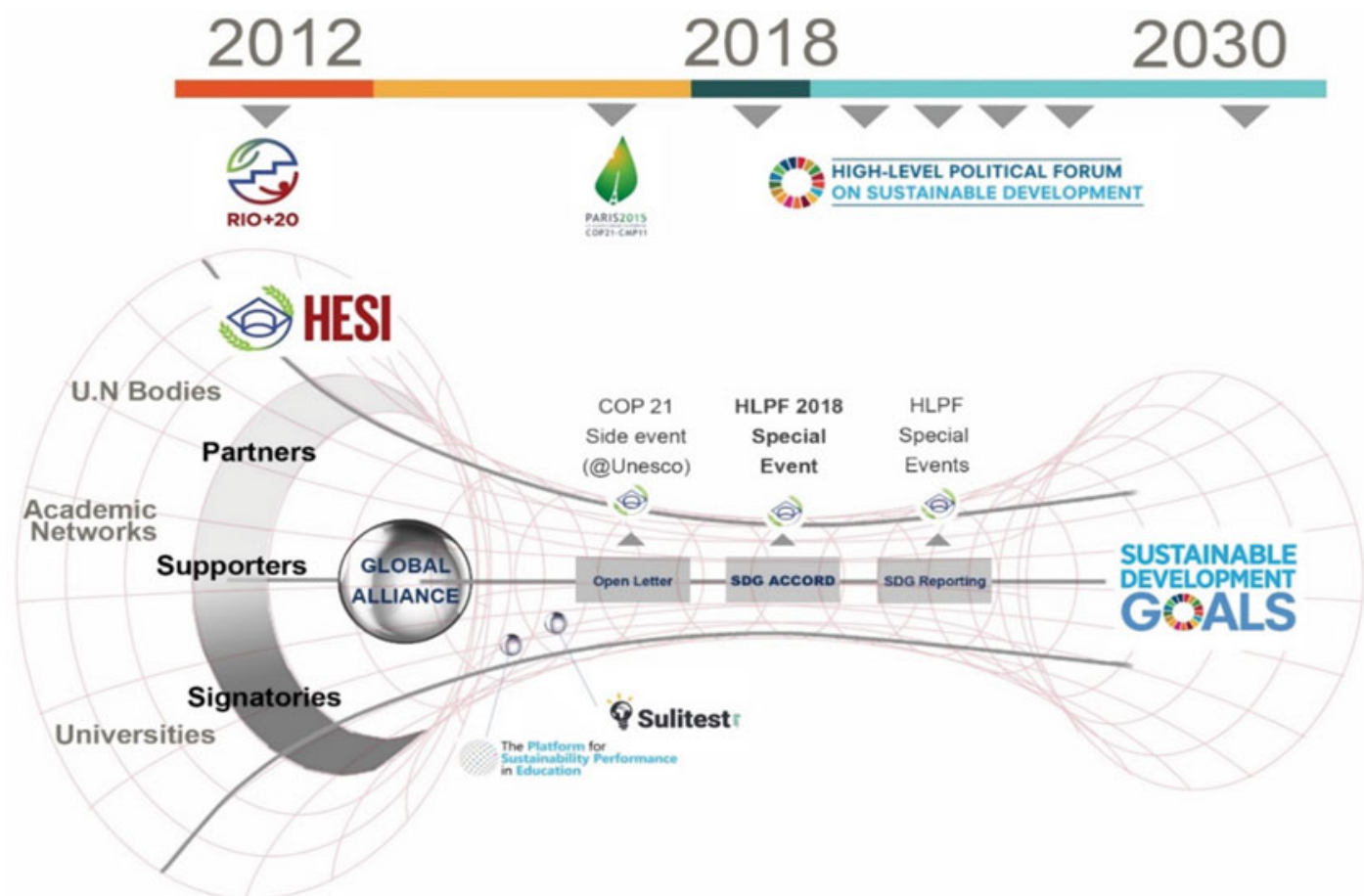

Global Alliance of Tertiary Education and Sustainable Development, Fig. 1 Timeline of the Global Alliance. (Copyright: EAUC)

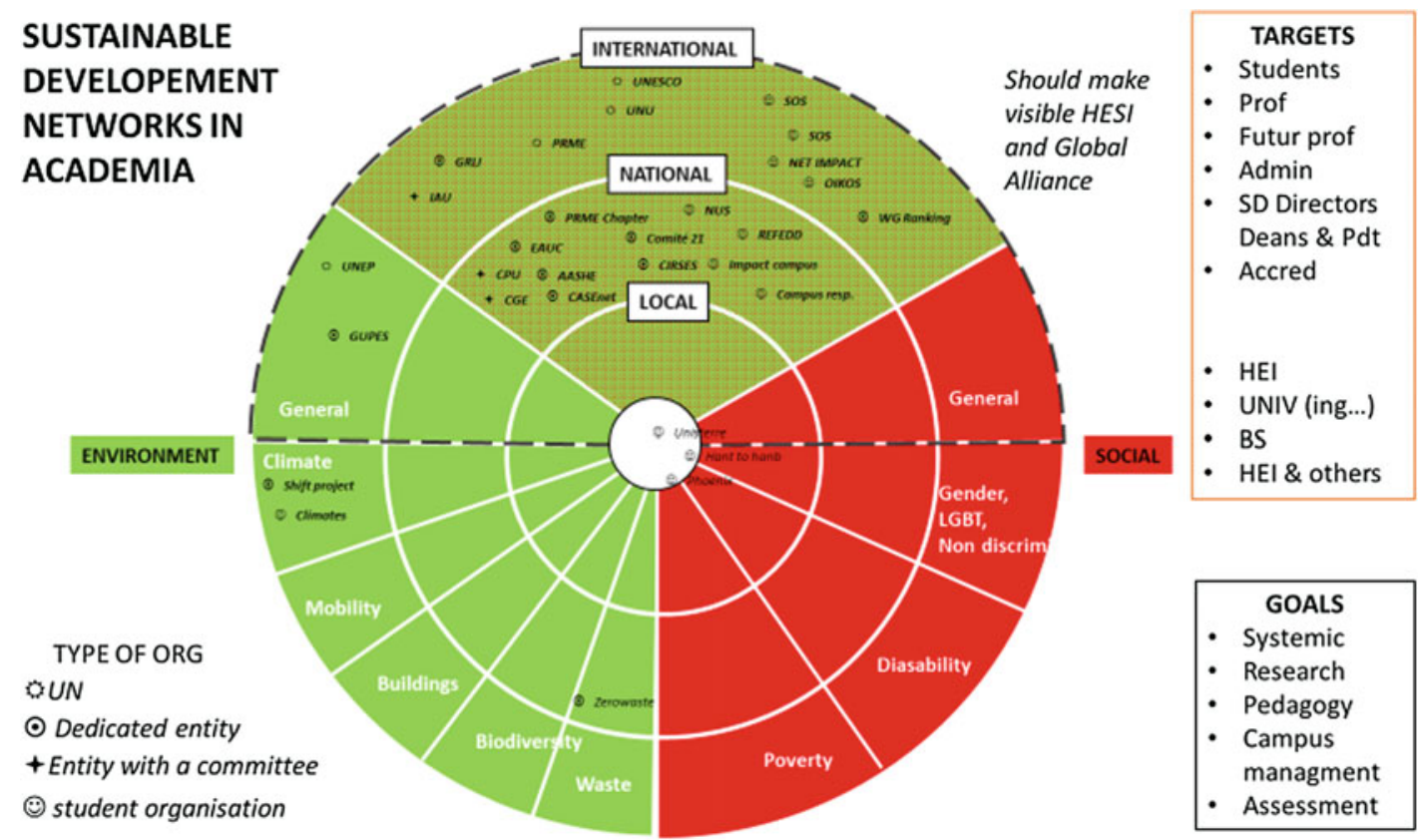

Global Alliance of Tertiary Education and Sustainable Development, Fig. 2 Suggested categorization of Global Alliance members. (Copyright: EAUC) 


\section{Australasian Campuses Toward Sustainability (ACTS)}

ACTS work to enable further and higher education institutions in the Australasia region (Australia, New Zealand, the island of New Guinea, and neighboring Pacific Islands) to work in collaboration to create sustainable institutions and practices (ACTS 2019a). The organization promotes best practice sharing and opportunities for collaboration for stakeholders in universities and colleges (ACTS 2019a). Members include higher education institutions in the Australasia region. Other organizations, such as businesses, NGOs, and government departments, can join through corporate or affiliate membership. Members have access to online learning resources and events, as well as eligibility for scholarships and Green Gown Awards Australasia (ACTS 2019c).

The organization is committed to the SDGs and provides resources for universities to engage with and embed the SDGs across the institution (ACTS 2019b). ACTS also deliver the Green Impact scheme, the Learning in Future Environments (LiFE) Index, as well as the Sustainability Tracking, Assessment and Rating System (STARS) in Australasia and arrange the International ACTS Conference (ACTS 2019a).

\section{Assessment Instrument for Sustainability in Higher Education (AISHE)}

The Assessment Instrument for Sustainability in Higher Education was launched in 2001 by the Dutch Committee for Sustainable Higher Education. The tool can be used to audit higher education institutions to see how well sustainability has been embedded throughout the university's curriculum (Roorda 2001). The aim of the assessment tool is to enable universities and colleges to assess their own sustainability performance. AISHE 2 assesses institutions through six indicators in five different modules: Identity, Education, Research, Operations, and Societal Outreach. Participating institutions can then be awarded Certificate of Sustainable Higher Education with a star rating betwee $D$ ind 4 (EAUC 2019b).

\section{Alianza de Redes Iberoamericanas de Universidades por la Sustentabilidad y el Ambiente (ARIUSA)}

ARIUSA brings together networks of higher education institutions working to enhance environmental sustainability in universities and colleges in Latin America, in the Caribbean, and in IberoAmerica. Twenty-five environmental networks are members of ARIUSA, representing 431 higher education institutions from 19 different countries (Sáenz 2018). The main aim of the alliance is to promote sustainability in higher education and to provide a platform for different environmental networks to come together over a common cause. The network is also committed to the SDGs and works to create synergy and collaboration toward the fulfillment of the goals (Sáenz 2018).

\section{Association for Promoting Sustainability in Campuses and Communities (APSCC)}

APSCC is an Indian-based organization, seeking to promote sustainability particularly in educational institutions and industry by providing a forum for information exchange, sharing of ideas and collaborations as a way to help foster partnerships between educational institutions, local communities, and other stakeholders to engender sustainable practices. The APSCC facilitates in the clarification and implementation of policies to help schools, colleges, universities, and other educational institutions to identify and implement sustainability-related initiatives that resonate with their local contexts.

The primary aim of APSCC is to promote "Environmental Sustainability in the Educational Institutions, Industries and upgrading the Quality of life for Marginalized \& Coastal Communities" (APSCC 2019). This will be achieved through promoting sustainable practices in wast ${ }^{\text {nage- }}$ ment, water, energy, biodiversity conservati ealthy foods, as well as transportation. Ultimately, the APSCC seeks to help protect and pass on to future generations a sustainable world. The organization seeks to embed "social, economical, ecological and environmental aspects of sustainability into the practices of the next generation of leaders" ensuring that such practices become 
second nat 2 Achievement of this aim will help toward achieving SDGs and deliver global prosperity for all.

Membership of the APSCC is oper $\square$ educationalists, business leaders, scientis professionals across many disciplines, economists and various others" (APSCC 2019) who are interested in collaborating on sustainability-related issues. Membership categories range from green councils, student members, individual members, as well as corporate members.

\section{Canadian College and University}

\section{Environmental Network (CCUEN)}

CCUEN works to develop and enhance environmental education in further and higher education across Canada. The organization connects environmental educators and stakeholders to promote quality education wit $\rightarrow$ he field of environmental sustainability. Twe seven universities were full members of the network in 2018 (CCUEN 2019 c) and have access to online resources as well as the annual CCUEN Conference (CCUEN 2019a). The organization's main mission is "To facilitate communication, information sharing and collaborative action among post-secondary environmental educators" (CCUEN 2019b).

\section{Campus Sustainability Network in Japan (CAS-Net Japan)}

CAS-Net Japan is a Japanese sustainability network that was set up in March 2014, primarily to coordinate sustainability initiatives between Japanese universities and promote cooperation on sustainability-related issues in tandem with similar initiatives around the world. The network was set up primarily to act as a platform for universities and other institutions involved in sustainability initiatives to share experiences and collaborate. By promoting cooperation within Japan, CAS-Net Japan ultimately seeks to build alliances with other global networks to further spearhead sustainability initiatives and create sustainable campuses.

\section{China Green University Network (CGUN)}

This is a network made up of higher education institutions that seek to promote sustainability and low carbon economies by combating climate change and embedding sustainable development practices into their curricula. The main aim of the network is to build capacity and equip higher education institutions in embedding the Green Universities Toolkit and transform their campuses into green campuses while reaching out and collaborating with different stakeholders in their localities and beyond.

\section{Conference des Grandes Ecoles (CGE), France}

The CGE is a French-based not-for-profit organization which was established in 1973 and seeks to equip higher education institutions in France and globally by offering a platform to facilitate accreditation, joint programs, and dissemination of information. The CGE seeks to act as a collaborative platform that brings together higher education institutions in France plus those abroad to collaborate on sustainability-related issues, working with partners drawn from companies as well as the not-for-profit sector.

The CGE membership comprises mainly of specialized management, engineering, and other specialized institutions seeking opportunities from collaborations nationally and/or abroad. The network also works closely with companies and the not-for-profit sector to widen participation (Grandes Ecoles 2019).

\section{The COPERNICUS Alliance}

This is a network of universities and colleges established in 1993 of the publication of the COPERNICUS C which saw 326 universities signing up and committing to promoting principles on sustainable development. It is registered as a non-for-profit organization in Germany. The network was relaunched in 2011 and renamad the COPERNICUS Alliance, and a new $\Omega_{a}$ was developed. Membership comprises mainly of individual and institutional members, the latter 
being universities and other higher education institutions (Copernicus 2019).

The Alliance seeks to facilitate the exchange of good practice among universities and colleges while building knowledge on sustainability and Education for Sustainable Development in higher education. It also seeks to inform and influence policy-making in relation to higher education in Europe and globally through development of tools and frameworks meant to help embed sustainability in higher education.

\section{EAUC: The Alliance for Sustainability Leadership in Education}

EAUC is the alliance for sustainability leadership in education, a not-for-profit, member-based charity, run by members for members. EAUC has 200 university, college, and learning and organizations as members. Membership is for the whole institution - staff and students - to ensure a holistic approach is taken to sustainability. EAUC also provides membership for companies. The alliance helps leaders, academics, and other professiopentainability to the heart of their ed ion institutions.

The alliance was formed as a volunteer organization in 1996 and has grown to represent over 2 million students and over 400,000 members of staff (EAUC 2019c). The aim of the association is to embed sustainability in all further and higher education institutions across the United Kingdom and Ireland. The EAUC offers a range of initiatives, such as the knowledge sharing platform Sustainability Exchange, an annual conference, and the Green Gown Awards (https://www. greengownawards.org), celebrating innovative sustainability initiatives in the college and university sector, both in the United Kingdom and internationally. The EAUC also leads on international initiatives such as the SDG Accord and the Global Alliance (Fig. 3).

\section{Ecocampus Belgium}

Ecocampus Belgium was initiated by the Flemish Government with the purpose of conscientizing the Flemish higher education sector toward sustainability. The initiative is divided into discipline-specific networks of educators who collaborate both in their disciplines as well as in multidisciplinary exchange forums facilitating knowledge sharing with different stakeholders. Ecocampus Belgium aims to incorporate sustainable development principles and values into the higher education curricula, focusing on education content, process, and vision. Five universities and 15 university colleges in Flanders are engaging with the initiative (Ecocampus 2019).

\section{Environmental Management for Sustainable Universities (EMSU) and International Journal of Cleaner Production}

EMSU use their international conference platform to bring together universities and other society stakeholders willing to tackle environmental challenges, to explore the role universities can play in developing solutions to address the sustainabilityrelated challenges faced by society. EMSU seek to promote a two-way dialogue between universities and society using their international conference to bring together key universities and other key stakeholders to collaboratively develop solutions for global environmental pressures.

\section{Foundation for Environmental Education (FEE)}

FEE was founded in 1981 in the Netherlands to "foster awareness, knowledge, participation, commitment, skills, actions and creativity on the environment and on sustainable development, sharing the core values behind the set of SDGs" (FEE 2019). The Foundation acts as facilitator for cultivating responsible consciousness through education. It runs educational programs such as EcoSchools, LEAF, as well as Young Reporters for the Environment, all aimed at conscientizing young people to proactively work toward creating a sustainable world. For organizations, the FEE runs Green Key and Blue Flag which both promote sustainable business practices. The foundation focuses on eight educational principles to act as pillars of their work in engendering a sustainability culture (FEE 2019, np). As stated on its 


\section{Our history}

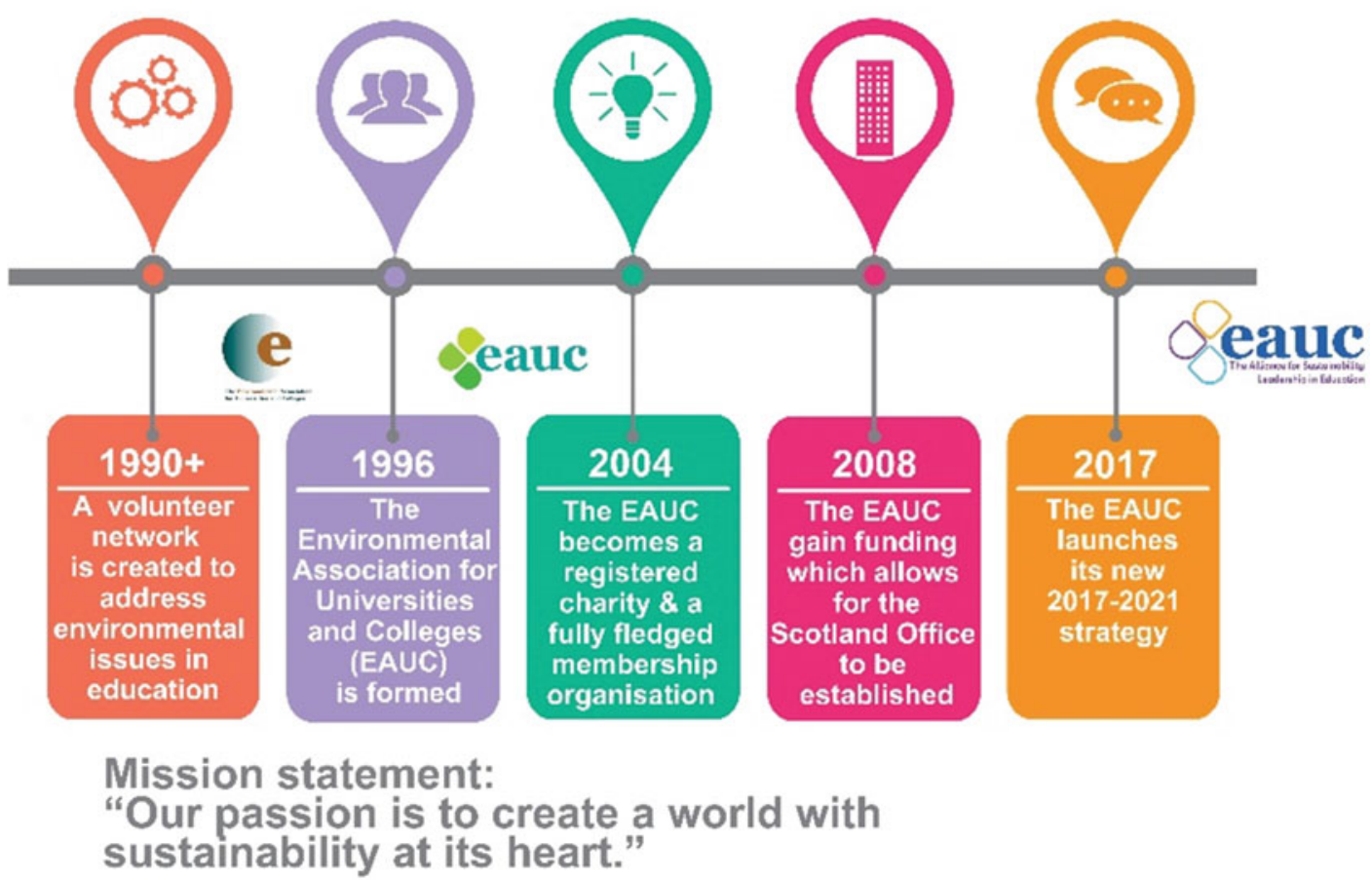

Global Alliance of Tertiary Education and Sustainable Development, Fig. 3 Timeline of the EAUC. (Copyright: EAUC)

website, the FEE seeks to "engage and empower people through education in collaboration with our members and partners worldwide" (FEE 2019).

\section{Globally Responsible Leadership Initiative (GRLI)}

The GRLI acts as a catalyst for the development of new innovative responsible leadership thinking worldwide. It fosters collaboration on ethics, responsibility, and sustainability between business schools and society by creating awareness of and the need to develop and promote responsible practices. They describe themselves as a "think-and-act enabler" as opposed to a think tank, emphasizing their "hands-on" approach. The main aim of the initiative is, through advocacy, to bring together diverse groups of people and facilitate the search toward solutions to address responsibility challenges facing the world and contribute toward SDGs. The GRLI is not a membership-based organization but rather a partnership of networks incorporating companies and learning institutions (GRLI 2019).

\section{Graines de Changement/Utopies}

Utopies is a French think tank established in 1993 with the aim to encourage and support organizations to develop and embed responsible practices into their strategies. The organization has since expanded its portfolio to offer consulting services and works in partnership with many blue-chip brands globally. The aim is to bring together organizations with an interest in sustainability-related issues and promote the development and deployment of sustainability thinking. The Campus Responsables "initiative" was created in 2006 to encourage and assist integration of sustainable development into educational institutions programs and the management of their infrastructure. Campus Responsables is the first network of universities and colleges focusing on sustainable 
development, with 40 member initiative institutions throughout France and Belgium. The French speaking Green Gown Awards - Les Trophées des campus responsables - are delivered by Campus Responsables.

\section{Higher Education Sustainability Initiative (HESI)}

HESI was formed in 2012 ahead of the United Nations Conference on Sustainable Development $(\mathrm{Rio}+20)$. It is a partnership between UNESCO, UNEP, PRME, the UN-Habitat, and UN-DESA aimed at creating a collaborative link between higher education institutions (HEIs), science, and policy-making as a way to usher in a more sustainable world through education. From inception, HESI garnered commitments from over 300 universities drawn from different parts of the globe. This represented more than a third of all sustainability commitments made and launched at the RIO+20 summit in 2012. HESI hosts various events where different stakeholders come together to share ideas, showcase their achievements of sustainability initiatives, as well as review progress toward such objectives as the 2030 sustainability objectives.

HESI aims to equip future generations with skills and knowledge to achieve the Sustainable Development Goals (SDGs). It seeks to achieve this objective by providing an effective and platform fostering collaboration ween higher education institutions (HEI, science, and policy-making. HESI also provides one of the most comprehensive and concrete opportunities to connect young people to the 2030 Agenda with over 300 higher education institutions drawn from around the globe committing to actively contribute toward HESI's sustainability agenda (HESI 2017). By working with several high-profile UN agencies, HESI puts the work of its different partners in the global limelight and helps to draw attention to sustainability challenges and how different initiatives are inching toward achievement of the SDGs. The HESI platform allows for different partners to gauge interest and commitment and understand the challenges faced by HEIs in their attempts to engender a sustainable culture among young people. This was manifested through the 2017 online survey that was commissioned by DESA-DSD to "better understand the interests, needs, and contributions of HEIs" (HESI 2017, p. 2). Thirty-six HEIs from around the world completed the survey with resounding support for the HESI platform and called for more support for HEIs in terms of sharing knowledge and fostering closer collaborations.

At the UN High Level Political Forum in July 2018, HESI UN Members rog orised the Global Alliance as its link with the worrds university and student sustainability n $\mathrm{n}$ rks and endorsed the SDG Accord and the Sumbt as its primary tools of engagement and support.

International Association of Universities (IAU) The IAU was formed in 1950 under UNESCO and remains an official partner of UNESCO. It is based in Paris, France, and has a worldwide membership base of over 650 higher education institutions, affiliates, and organizations drawn from over 130 countries worldwide (IAU 2019). The association was formed to foster collaboration among higher education institutions from around the world.

\section{International Sustainable Campus Network (ISCN)}

The ISCN is a forum that offers a global platform to facilitate exchange of information and best practice among universities, colleges, and corporates from around the world, driving the search for sustainability solutions and fostering the integration of sustainability into research and teaching. ISCN boasts of over 80 university members from over 30 countries worldwide. Most of the members of the World Economic Forum's Global University Leader Forum are also members of ISCN. All members must sign the ISCN charter and commit to produce their own charter that they will transparently deliver on and report results thereof as well as pay their annual membership fee (ISCN 2019). 


\section{Korean Association for Green Campus Initiative (KAGCI)}

KAGCI works to enhance sustainable education, research, and campuses by creating practical, collaborative opportunities between educational institutions and local communities (KAGCI 2010a). The aim e association is to make long-term commitı to sustainable campuses, reduction of energy and greenhouse gas emissions, and green leadership in the higher education sector (KAGCI 2010b). KAGCI also aims to support universities by providing them with training and resources to put in place adequate measures to create environmentally responsible campuses and green curriculums. The association connects 39 Korean institutions (KAGCI 2010c) interested in creating green campuses and enables both national and international collaboration toward sustainable development (KAGCI 2010b). Each member university has a committee working with 0 ims and goals of KAGCI and is responsible to spread information and organize projects and events in line with the values of the association (KAGCI 2010b).

\section{Mainstreaming Environment and Sustainability in Africa (MESA)}

The MESA Partnership is an initiative from the United Nations Environment, supported by UNESCO, United Nations University (UNU), and the Association of African Universities (AAU). Eighty-five universities in 32 different African countries are members, and the Partnership runs and contributes to a wide range of sustainability initiatives, including online resources to support embedding Education for Sustainable Development in universities and platforms to share good practice relating to sustainability education, research, and engagement (MESA 2019).

The main aim of MESA is to embed themes of sustainable development into all aspects of university life. Focus is also on providing African higher education institutions with a framework to mainstream Education for Sustainable Development in their practices and continue to engage students with sustainability.

\section{National Institute of Technology, Fukushima College}

Fukushima College is the organizer of the Regional Conference on Campus Sustainability, focusing on creating campuses and communities enhancing sustainability and green spaces. In 2019, the main theme of the conference is "Renewable Energy and Campus Sustainability."

\section{Nordic Sustainable Campus Network (NSCN)}

NSCN was launched in 2012 to further enhance sustainability initiatives in Nordic colleges and universities. The network recognizes the importance of education in reaching sustainability goals and aims to enhance sustainability themes in learning and teaching, estates, and operations (NSCN 2019a). The NSCN engages sustainability professionals across further and higher education institutions in the Nordic countries. Forty-five institutions are currently members of the network (NSCN 2019b). The network encourages collaboration and sharing of good practices between members by facilitating online platforms, such as blogs, mailing lists, and LinkedIn groups (NSCN 2019a). The network organizes external events around sustainability themes and leads projects such as the Nordic City Challenge, a collaborative and interdisciplinary urban development project engaging students in the Nordic countries (NSCN 2019a).

\section{National Union of Students (NUS)}

NUS represents around $95 \%$ of all college and university students' unions in the United Kingdom. Six hundred local student unions are part of the NUS, and the organization represents the interests of seven million students in the United Kingdom (NUS 2019a).

NUS protects the rights of students in further and higher education and is offering a wide range of opportunities on matters relevant for student life. The organization's three core values have been identified as equality, democracy, and collectivism (NUS 2019a), aiming to build a resilient and impactful organization. The sustainability department runs events such as the Green Impact scheme, the Responsible Futures accreditation, and the Student Switch Off, engaging students in 
making their campuses, curriculums, and communities more sustainable (NUS 2019b).

\section{ProSPER.Net: Promotion of Sustainability in Postgraduate Education and Research Network}

ProSPER.Net was launched in 2008 and connects higher education institutions in the Asia-Pacific region on Education for Sustainable Development in postgraduate courses. The network focuses on embedding sustainability across a wide range of academic disciplines for a higher impact and outreach. Forty-six institutions from the whole Asia-Pacific region are currently members of the network (ProSPER.Net 2019).

The network aims to foster responsible leaders with the right skills, knowledge, and abilities to solve future and contemporary sustainability challenges. By embedding sustainability themes in the formal curriculum, students will be better equipped to be part of future solutions and make a positive difference.

\section{Rootability}

Rootability is a nonprofit social business, recognizing the student demand for greener educational institutions from both students and staff. Rootability aims to provide opportunities and resources for people to take action in their own institutions (Rootability 2019a), by engaging students and staff in sustainability projects and events, such as the "Green Office Model," an open-source solution aiming to involve whole institutions in sustainability initiatives. In 2019, there were Green Office initiatives in close to 70 institutions across the world (Rootability 2019b).

\section{Studenten voor Morgen}

Studenten voor Morgen is the Dutch national student network for sustainability in higher education. They connect student organizations interested in sustainability from across the Netherlands, with 40 organizations currently part of the network. The aim of the network is to provide students with the right knowledge and tools to live a sustainable life and to make a difference. In addition, they aim to further enhance sustainability in curriculum, research, and operations in higher education institutions across the Netherlands. The network uses the SDGs as a framework, which can be seen through a wide range of projects and resources made available by the organization, including a monthly magazine and the sustainability ranking tool SustainaBul (Studenten voor Morgen 2019).

\section{Sustainability and Education Policy Network (SEPN)}

Launched in 2012, SEPN is an international network of researchers and institutions responding to the need for sustainability education policy research. The organization enables collaboration between researchers within the field of sustainable development and international policy research (SEPN 2019a). The network engages 11 Partner and Contributor Organizations as well as academics, graduate students, and research fellows (SEPN 2019b).

SEPN aims to explore how educational systems are contributing toward sustainable development and how to align educational policy to efficiently combat sustainability challenges (SEPN 2019b). The network enables partnerships between researchers, policy-makers, and organizations to create research opportunities and collaborations on a global and national scale (SEPN 2019a).

\section{Sustainable University Network of Thailand}

SUN Thailand is a group of 20 higher education institutions working toward sustainable campuses and curriculums (SUN Thailand 2019). The network recognizes the need for educational institutions to contribute to sustainable development by establishing sustainable policies and operations and aims to link Thai universities interested in making a difference to both national and international networks. The network also wants to set an example and share good practice for other sectors to follow (SUN Thailand 2019).

\section{UK Youth Climate Coalition (UKYCC)}

UKYCC is a group consisting of people aged $18-29$, focusing on raising awareness of environmental problems. The organization offers ways 
for young people to get involved and make their voices heard. The group was set up as a response to the climate change mobilizati $\bigcirc$ young people across Europe and the wo nnd aims to highlight the urgency to act on climate change and environmental challenges. The organization wants to empower young people to take action and collaborate with like-minded people to create maximum impact (UKYCC 2019b). In 2019, they mobilized youths around the United Kingdom to take part in the climate strike, demanding leaders worldwide to act on climate change (UKYCC 2019a).

\section{United Nations Environment (UNE)}

UNE is a UN body focusing on global environmental challenges, setting the environmental agenda and contributing to solutions in member states (UN Environment 2019a). Their work is categorized into seven themes: climate change, disasters and conflicts, ecosystem management, environm governance, chemicals and waste, resource ent, and environment under review (UNE 2019b).

UNE collaborates with a range of stakeholders, including research networks, other UN bodies, and educational institutions, to adequately tackle some of the main environmental challenges we are facing today. Their main aim is to provide leadership and opportunities for collaboration and partnership building around environmental themes and projects. UNE wants to enable all nations to take action and ensure quality of life for current as well as future generations (UN Environment 2019b). UNE supports the International Green Gown Awards.

\section{International Alliance of Research Universities (IARU)}

IARU, founded in 2006, is a network of research universities focusing on solving some of the biggest sustainability challenges of our time. By bringing together some of the most renowned higher education institutions around a common theme, can opportunities for collaboration and exchange develop on a global level? The network offers opportunities for staff and students to develop vital skills through internship schemes and summer courses, aiming to foster global citizenship and international collaboration (IARU 2019a).

The main aim of IARU is to enable future leaders to develop skills and knowledge that will allow them to make responsible decisions and contribute to positive change. Academic diversity and international collaboration are two key aspects of IARU's vision (IARU 2019a). Eleven universities from nine different countries are currently part of the network. The members collaborate around the main themes of the alliance, orgar joint projects, and share best practice with her regularly (IARU 2019b).

\section{US Partnership for Education for Sustainable Development (USPESD) and the Disciplinary Associations Network for Sustainability (DANS)}

USPESD is a network launched in 2003, working to enhance sustainability education in the American education system and ensure that sustainability themes are fully integrated in educational institutions across the United States (USPESD 2019b). The partnership consists of around 100 participants representing a wide range of stakeholders, from faith communities to environmental NGOs and higher education institutions (USPESD 2019a).

DANS is an informal network, coordinated by the USPESD and the Association for the Advancement of Sustainability in Higher Education (AASHE). The network consists of 40 academic associations and stakeholders interested in enhancing Education for Sustainable Development across the further and higher education sector (AASHE 2019d).

\section{Key Project of the Global Alliance: SDG Accord}

The SDG Accord was launched in September 2017 with the aim to highlight the vital role education plays in contributing to the fulfillment to the SDGs and show the sectors commitment to the Goals. The initiative was initiated by the Global 
Alliance of tertiary education and is led by the EAUC (SDG Accord 2019a).

The SDG Accord is open for anyone to sign through the website www.sdgaccord.org. Signatories are encouraged to show their commitment to the SDGs and continuously develop their practice to contribute to the fulfillment of the goals. Over 800 individuals, 100 institutions, and 14 students' unions worldwide have signed the Accord (February 2019). The SDG Accord is also endorsed by members of the Global Alliance, such as the COPERNICUS Alliance, the UN PRME, and the International Sustainable Campus Network. The SDG Accord is also an officially recognized tool of the UN Partnership Higher Education Sustainability Initiative (HESI) (SDG Accord 2019b).

Signatories have access to resources relating to the SDGs such as case studies and webinars as well as the online discussion group the $S D G$ Accord Learning Network (SDG Accord 2019c), a place for discussions and sharing experiences, bringing together students, academics, and HE professionals from across the globe.

Institutional signatories are required to report on how they are contributing to the fulfillment goals by submitting yearly reports on their progress. The questions given to the reporting signatories ask, for example, on how each goal is embedded in leadership, education, research, operations, administrations, and/or engagement activities and future plans the HEI might have in addressing the goals. While giving evidence and links to the initiatives within their institutions, HEIs are asked to assess themselves with regard to their efforts. They can choose to share some of their best practices with the sector. Combining all these reports, an overview of how the HE sector as a whole is addressing the SDGs is presented annually at the UN High-Level Political Forum. In July 2018 the first SDG Accord report was launched, containing case studies, best practice, and recommendations from signatories across the globe (SDG Accord 2019d).

Going forward, institutions will be encouraged to submit more detailed reports on the SDGs. Currently, reporting signatories are invited to present the evidence, but it is not mandatory that they do so. It is envisaged that leading institutions will be keen to provide the evidence and share their best practice more widely.

\section{Cross-References}

- Accreditations

$\checkmark$ Oikos International

Sulitest

- Sustainable Development Solution Network

- UN Principles of Management Education

\section{References}

AASHE (2019a) History of AASHE. http://www.aashe. org/about-us/aashe-history/. Accessed 28 Feb 2019

AASHE (2019b) Who we are. http://www.aashe.org/ about-us/who-we-are/. Accessed 28 Feb 2019

AASHE (2019c) What we do. http://www.aashe.org/ about-us/what-we-do/. Accessed 28 Feb 2019

AASHE (2019d) DANS. https://www.aashe.org/partners/ dans/. Accessed 01 Mar 2019

ACTS (2019a) About us. https://www.acts.asn.au/aboutus/. Accessed 28 Feb 2019

ACTS (2019b) Support the SDGs. https://www.acts.asn. $\mathrm{au} / \mathrm{wwd} / \mathrm{sdgs} /$. Accessed 28 Feb 2019

ACTS (2019c) Membership. https://www.acts.asn.au/mem bership/. Accessed 28 Feb 2019

APSCC (2019) Association for promoting sustainability in campuses \& communities. http://www.apsccindia.org/. Accessed 28 Feb 2019

CCUEN (2019a) About us. https://www.ccuen-rccue.ca/ en/about-us/about-us. Accessed 28 Feb 2019

CCUEN (2019b) Mission and vision. https://www.ccuenrccue.ca/en/about-us/mission-and-vision. Accessed $28 \mathrm{Feb} 2018$

CCUEN (2019c) Members. https://www.ccuen-rccue.ca/ en/members. Accessed 28 Feb 2018

Copernicus (2019) About. https://www.copernicusalliance.org/ca-members. Accessed 03 Mar 2019

Cortese AD (2003) The critical role of higher education in creating a sustainable future. Plan High Educ 31(3): $15-22$

Dyer G, Dyer M (2017) Strategic leadership for sustainability by higher education: the American College and University Presidents Climate Commitment. J Clean Prod 140:111-116

EAUC (2019a) Global alliance. https://www.eauc.org.uk/ global_alliance. Accessed 04 Mar 2019

EAUC (2019b) AISHE. http://www.eauc.org.uk/ theplatform/aishe. Accessed $27 \mathrm{Feb} 2018$

EAUC (2019c) What we do. https://www.eauc.org.uk/ what_we_do. Accessed 27 Feb 2019 
Ecocampus (2019) Ecocampus. https://www.sustainabil ityexchange.ac.uk/ecocampus_belgium. Accessed 03 Mar 2019

FEE (2019) Foundation for environmental education. http://www.fee.global/our-work. Accessed 28 Feb 2019

Fien J (2002) Advancing sustainability in higher education: issues and opportunities for research. High Educ Pol 15:143-152

Grandes Ecoles (2019) Grandes Ecoles. www.studyrama grandesecoles.com. Accessed 04 Mar 2019

GRLI (2019) Our network. https://grli.org/about/ournetwork/. Accessed 03 Mar 2019

HESI (2017) 2017 Higher education sustainability initiative report. https://sustainabledevelopment.un.org/con tent/documents/17374HESI_2017_Report.pdf. Accessed 28 Feb 2019

IARU (2019a) About. http://www.iaruni.org/about/aboutiaru. Accessed 01 Mar 2019

IARU (2019b) IARU members. http://www.iaruni.org/ about/members. Accessed 01 Mar 2019

IAU (2019) International Association of Universities. https://iau-aiu.net/. Accessed 03 Mar 2019

ISCN (2019) Membership overview. https://www. international-sustainable-campus-network.org/member ship/overview. Accessed 03 Mar 2019

KAGCI (2010a) Vision. http://kagci.org/eng/subpage. php? $\mathrm{p}=\mathrm{m} 12$. Accessed 28 Feb 2019

KAGCI (2010b) Our tasks. http://kagci.org/eng/subpage. php? $\mathrm{p}=\mathrm{m} 13$. Accessed 28 Feb 2019

KAGCI (2010c) History of KAGCI. http://kagci.org/eng/ subpage.php? $\mathrm{p}=\mathrm{m} 14$. Accessed 28 Feb 2019

Lozano R (2011) The state of sustainability reporting in universities. Int J Sustain High Educ 12(1):67-78

Lozano R, Lukman R, Lozano FJ, Huisingh D, Lambrechts W (2011) Declarations for sustainability in higher education: becoming better leaders, through addressing the university system. J Clean Prod 2011:1-10

MESA (2019) UN Environment - Mainstreaming Environment and Sustainability in Africa (MESA) Universities Partnership. https://www.unenvironment.org/ explore-topics/education-environment/why-doeseducation-and-environment-matter/global-2. Accessed 01 Mar 2019

NSCN (2019a) About NSCN. https://nordicsustainable campusnetwork.wordpress.com/about-nscn/. Accessed 01 Mar 2019

NSCN (2019b) NSCN members. https://nordicsustainable campusnetwork.wordpress.com/nscn-members/. Accessed 01 Mar 2019

NUS (2019a) What we do. https://www.nus.org.uk/en/ who-we-are/what-we-do/. Accessed 01 Mar 2019

NUS (2019b) NUS sustainability. https://sustainability. nus.org.uk/. Accessed 01 Mar 2019
Roorda N (2001) AISHE - Auditing instrument for sustainability in higher education. https://www.sustainabil ityexchange.ac.uk/files/aishe-book1_5.pdf. Accessed 28 Feb 2019

Rootability (2019a) About us. http://rootability.com/aboutus/. Accessed 01 Mar 2019

Rootability (2019b) Green office model. http://rootability. com/green-office-model/. Accessed 01 Mar 2019

Sáenz O (2018) Alliance of networks for environmental sustainability of higher education institutions in IberoAmerica, in approaches to SDG 17 partnership for the sustainable development goals (SDGs), 2018, pp 60-74. https://www.sustainabilityexchange.ac.uk/ files/2018-11-13_osz_ariusa_and_sdgs_003.pdf. Accessed 28 Feb 2019

SDG Accord (2019a) About. https://www.sdgaccord.org/ about. Accessed 27 Feb 2019

SDG Accord (2019b) The SDG accord - The University and College Sector's Collective Response to the Global Goals. https://www.sdgaccord.org/. Accessed 27 Feb 2019

SDG Accord (2019c) SDG accord learning network. https://www.sdgaccord.org/sdg-accord-learning-net work. Accessed 27 Feb 2019

SDG Accord (2019d) Reporting. https://www.sdgaccord. org/reporting. Accessed 27 Feb 2019

SEPN (2019a) About us. https://sepn.ca/the-project/. Accessed 01 Mar 2019

SEPN (2019b) People. https://sepn.ca/the-project/people/. Accessed 01 Mar 2019

STARS (2019) About STARS. https://stars.aashe.org/ about-stars/. Accessed 28 Feb 2019

Studenten voor Morgen (2019) Missie en visie van Morgen. https://www.studentenvoormorgen.nl/over-ons/. Accessed 01 Mar 2019

SUN Thailand (2019) Sustainable University Network of Thailand. http://www.sunthailand.org/eng/index.html. Accessed 01 Mar 2019

UKYCC (2019a) Climate action. https://ukscn.org/. Accessed 01 Mar 2019

UKYCC (2019b) Mission. https://ukscn.org/mission. Accessed 01 Feb 2019

UN Environment (2019a) About UN, environment. https:// www.unenvironment.org/about-un-environment. Accessed 01 Mar 2019

UN Environment (2019b) Why does UN environment matter? https:/www.unenvironment.org/about-unenvironment/why-does-un-environment-matter. Accessed 01 Mar 2019

USPESD (2019a) History. https://uspartnership.org/pages/ brief-history. Accessed 01 Mar 2019

USPESD (2019b) Mission and vision. https:// uspartnership.org/pages/mission-vision. Accessed 01 Mar 2019 